\title{
A Survey on Capital Structure Decision of Nepalese Non-Financial Firm
}

\author{
Shanker Dhodary \\ Lecturer, Nepal Commerce Campus
}

\begin{abstract}
The study aims at examining the views of capital structure in Nepalese non-financial enterprises. The study is based on primary data. A descriptive research design has been adopted for the study. Different descriptive statistical measures such as minimum, maximum, percentage, average, standard deviation and coefficient of variation have been used to analyze. This study is directed towards examining the capital structure policy of Nepalese non-financial firms. The primary information required for the said purpose has been collected through the survey of opinions of board of directors, company secretary, executives, chief fiancé officers and other line managers through administering the well structure multi- part questionnaire. For the purpose of field survey, 90 questionnaires were distributed among the respondents located in Kathmandu using non probabilistic sampling. The survey result shows that preference toward maturity structure of borrowing varied among the Nepalese non-financial firms, and majority of Nepalese firms do not consider interest rate and practice of matching between asset and liabilities structure while they go for borrowing. As proper matching between assets and liabilities structure is required, companies should pay attention towards this aspect. Outside security analysts and comparative industry have only a minimal effect on the development of these targets.
\end{abstract}

Key words: Capital structure, leverage, liquidity, profitability, Tangibility, firm's size

\section{Introduction}

A firm's capital structure is the combination of a firm's equity, debt, and hybrid securities which finances the whole business operation. A capital may be composed of equity, debt or even hybrid securities. The comparison ratio between the equity and the debt is usually known as the leverage. The pioneers of the determinants of corporate capital structure are Modigliani \& Miller (1958), which published their work almost half a century ago.

Since the seminal work of Modigliani and Miller (1958), the basic question of whether a unique combination of debt and equity capital maximizes the firm value, and if so, what factors could influence a firm's optimal capital structure has been remained the subject of frequent debate in the literature corporate financial management. Based on very restrictive assumptions of perfect capital markets, homogenous expectations, no taxes and no transaction costs, Modigliani and Miller concluded that capital structure does not affect the firm's market value. In short, capital structure is irrelevant to the value of firm.

In addition to capital structure irrelevance, there are alternative theories of capital structure that include: trade- off theory, pecking order theory and agency 
theory (Pandey, 2001). The trade-off theory of corporate financing is built around the concept of target capital structure that balances various costs and benefit of debt and equity. In contrast to trade-off theory, the pecking order theory of Mayers and Majluf (1984) contends that firms follow a financing hierarchy, in which firms prefer internal financing to debt first and debt to equity when external funds have to be raised.

Most of the studies undertaken in the field of corporate finance have attempted to explain the capital structure by looking into several determinants of capital structure under different theoretical frameworks. Studies have attempted to consider firms specific, industry characteristics and country characteristics (Rajan \& Zingales, 1995). However, their conclusions are different in accordance with sample characteristics, methodology and data set used in the study. Further, studies have documented various factors affecting corporate financial leverage.

It has been well documented in the literature that a firm's debt level is influenced by its size (Gupta, 1969; Titman \& Wesseles, 1988). The trade-off theory states that large firms tend to be Many studies have examined growth variable as one of the determinant of corporate financial leverage. According to pecking order theory, the growing firm may have higher level of debt as growing firms may not have adequate retained earnings and go for debt as against to equity. According to the trade-off hypotheses, tangible assets act as collateral and provide security to lenders in the events of financial distress. Consequently, collateral value (fixed assets to total assets) is found to be major determinants of the level of leverage.

In addition to international context, several studies have also been conducted in Nepalese context to examine the determinants of corporate capital structure. These studies have also come up with more or less similar contradictory results as in the studies of other countries. Therefore, theories of capital structure are still not immunized against the dispute on what factors would guide the management to determine the proper leverage ratio.

In view of above context and reality, the present study has been undertaken with the objective of examining the views of corporate executives and finance officers with respect to impact of capital structure.

\section{Literature review}

The theory of capital structure begins with the capital structure irrelevance proposition of Modigliani and Miller (1958). They explained that in perfect capital markets, the financing decisions of firms have no effect on their value. M-M confirmed that in the absence of bankruptcy costs, corporate income taxation, or other market imperfections, firm value is independent of its financial structure in competitive capital markets. They have two propositions under these conditions. First, they inferred that the value of a company is not dependent upon its capital structure. Additionally, the cost of a leveraged firm is the same as the cost of equity for an unleveraged firm.

Therefore, according to M-M, the debt-to-equity ratio has no impact on the total value of a firm. However, based on this theory, within the literature there are three main theories of capital structure: the trade-off theory, the pecking order theory, and the agency theory. This section presents review of major theories on capital structure.

Myers and Majluf (1984) have argued that if managers have better information about the future investment opportunities of the firm than the potential investor, 


\section{Pravaha Journal-2018}

they might find it difficult to get external finance. This is because outsiders ask for a premium in order to compensate for the possibly of finding a bad firm. If the firm tries to finances its new projects by issuing equity, then the under-pricing may be so severe that a good firm may find it profitable to reject some of its projects even with positive net present value (NPV). Thus the firm will always try to choose a security, which minimizes this problem known as Lemon problem. The internal sources of funds, however, do not suffer from such a problem.

Similarly, debt will prefer to equity because the possibility of under-pricing is much less here. Thus, capital structure choice will be driven by a hierarchical performance. First, internal funds are selected, and then the risk debt and, finally equity. This hypothesis, known as "pecking order Hypothesis", is valid for the corporate financing pattern of the developed countries where internal funds occupy the first position in the pecking order of funds.

The study on the financial leverage in Indian context (Pandey, 1985) revealed that the level of leverage in the Indian industry is moving upwards and that the large majority of companies leverage decisions seem to be independent of their size, profitability, growth and industrial variations.

Rajan and Zingales (1995) examined the difference in leverage and its determinants in G7 countries: USA, Japan, Germany, France, Italy, UK and Canada. It was a cross country investigation of capital structure determinants directed towards examining whether or not factors identified in United States seem similarly related in other countries as well. The study found aggregate leverage and determinants are both roughly identical across these countries.

McConnell and Servaes (1995) have analyzed a large sample of non- financial United State firms for the years 1976, 1986 and 1988. They showed that for high growth firms, the relationship between corporate value and leverage is negatively correlated. Also the allocation of equity ownership between corporate insiders and other types of investors is more important in low growth than in high growth firms.

Based on an analysis of the relationship between the debt ratio and the rate of growth of companies, (Lang et al., 1996) pointed out that for companies with fewer investment opportunities (i.e. companies with a low Tobin's Q), there is a negative correlation between the debt ratio and the investment. The estimation results from their studies did not find a negative correlation between the debt ratio and the growth rate for companies with abundant growth opportunities. In other words, for companies with investment opportunities, increased liabilities do not necessarily hamper growth.

Schiantarelli and Sembenelli (1997) observed that the firms tend to match assets with liabilities, and more profitable firms have more long-term debt. Long-term debt has a positive effect on firm's performances. But this is not true when a large fraction of that debt is subsidized. Further the study revealed that due to their inherent high risk and lack of liquidity early-stage companies are not able to employ higher debt in their capital structure.

Kakani (1999) attempted to find out the determinants of the capital structure and its maturity in Indian firms. The study had analyzed measure of short-term and long-term debt rather than an aggregate measure of total debt. Based on analysis, the study revealed that profitability; capital intensity and non-debt tax shields are the important determinants of capital structure. 
Huang and Song (2006) used a new data set of both market and accounting value to analyze the capital structure models in more than 1000 Chinese listed companies over the period 1994-2000. The study indicated the same findings as Booth et al. (2001) that firms in developing countries tend to have lower long-term debt. Moreover, 'as in other countries, leverage in Chinese firms increased with firm size, non-debt tax shields and fixed assets and decreases with profitability and correlated with industries'. However, results different from others was that debt in Chinese firms had a negative relationship with earnings volatility.

Baral (2004) made an attempt to examine the determinants of capital structuresize, business risk, growth rate, earning rate, dividend payout, debt service capacity and degree of operating leverage-of the companies listed to Nepal Stock Exchange Ltd. as of July 16, 2003. Eight variables multiple regression model has been used to assess the influence of defined explanatory variables on capital structure. In the preliminary analysis, manufacturing companies, commercial banks, insurance companies and finance companies were included. However, due to the unusual sign problem in the constant term of the model, manufacturing companies were excluded in final analysis.

\section{Research methodology}

\subsection{Research design}

The descriptive research design has been adopted to search adequate information in the context of corporate capital structure, and assess the opinions of respondents of the survey. Different descriptive statistical measures such as minimum, maximum, percentage, average, standard deviation and coefficient of variation have been used to analyze.

\subsection{Nature and sources of data}

Data required for undertaking the study has been collected from primary sources. In addition to analyze the secondary information, an attempt has also been made to check and validate the study findings through opinion survey of major stakeholders of the non- financial firms covered under the study.

\subsection{Population and sample}

This study is directed towards examining the capital structure policy of Nepalese non- financial firms. Therefore, all listed non- financial firms in NEPSE constitutes the population of the study. These firms represent trading, manufacturing and processing, hotels and hydropower sectors as classified by the NEPSE. The primary information required for the said purpose has been collected through the survey of opinions of board of directors, company secretary, executives, chief fiancé officers and other line managers through administering the well structure multi- part questionnaire.

For the purpose of field survey, 90 questionnaires were distributed among the respondents located in Kathmandu using non probabilistic sampling. Ethical standard of researcher was maintained by taking their prior consent. Only 82 usable questionnaires were collected.

\subsection{Data processing and analysis}


Information collected from different source have been compiled and coded as per requirement. Necessary tables have been prepared for the further analysis. Analysis has been done using both quantitative and qualitative assessment framework to draw the meaningful conclusions. Efforts have been extended to cover analysis of various qualitative aspects affecting the corporate financial leverage choice of the selected Nepalese non-financial enterprises.

\section{Presentation and analysis of data}

\subsection{Perception of respondents' on the impact of corporate capital structure}

The survey participants were asked about their perception on impact of corporate capital structure. In this connection, four different questions were asked to them. The first question was related with their belief on functional relationship between cost and amount of debt utilize in capital structure. This question was then altered slightly and participants were asked whether or not they think sue of proper amount of debt would result in a lower cost of capital in their corporations. The responses to these two questions are approximately identical. Of the 82 respondents, 84.15 percent answered in favor of first question, and 87.80 percent reported similarly to second question. It shows that respondents have belief on role of the prudent use of leverage on lowering the firm's average financing costs.

Table 1: Impact of corporate capital structure on cost of capital and bankruptcy

\begin{tabular}{lcccc}
\hline \multicolumn{1}{c}{ Questions } & Yes & No & Don't Know & Total \\
\hline $\begin{array}{l}\text { Does your firm believe on functional relationship } \\
\text { between capital cost and amount of debt utilize in }\end{array}$ & 69 & 8 & 4 & 71 \\
capital structure? & $(84.15)$ & $(9.76)$ & $(6.09)$ & $(100)$ \\
Does your firm believe that use of proper amount will & 72 & 7 & 3 & 71 \\
result in a lower overall cost of capital? & $(87.80)$ & $(8.54)$ & $(3.66)$ & $(100)$ \\
Does your firm believe that the use of excessive & 73 & 3 & 6 & 71 \\
amount of debt will eventually results in an increase & $(89.02)$ & $(3.66)$ & $(7.32)$ & $(100)$ \\
cost of debt? & 77 & 2 & 3 & 71 \\
Does your firm believe that excessive use of debt will & $77.90)$ & $(2.44)$ & $(3.66)$ & $(100)$ \\
\hline eventually pushes the firm towards bankruptcy? & $(93.90)$
\end{tabular}

Respondents were also asked to express their belief on the impact of excessive use of debt in firm's capital structure. In this connection, first question was directed to understand their belief on the impact of excessive use of debt in an increased cost of debt while second was directed to understand their belief on impact of excessive use of debt towards bankruptcy of the firm. Of the 82 respondents, 73 (89.02 percent) indicated yes with respect to first question, and 77 (93.90 percent) expressed that excessive use of debt pushes towards bankruptcy of the firm reported. The survey indicated that the great majority of respondents are well aware about the negative consequences of employing excessive debt in firm's capital structure.

\subsection{Impact of use of higher debt ratio compared to other similar firms}

An attempt was made to understand the perception of survey participants towards the impact of employing higher debt ratio compared to other similar firms in the industry. Accordingly, respondents were asked to express their opinion on whether 
risk of the firm increases or decreases, share price will increase or decrease or nothing will happen.

Table 2: Impact of use of higher debt ratio compared to other similar firms

\begin{tabular}{llccc}
\hline Impact & Unit & Responses & Percent & Cumulative Percent \\
\hline Risk of the firm increases & No. & 62 & 75.61 & 75.61 \\
Risk of the firm decreases & No. & 0 & 0.0 & 75.61 \\
Share price of the firm's stock will increase & No. & 2 & 2.44 & 78.05 \\
Share price of the firm's stock will decrease & No. & 18 & 21.95 & 100 \\
Nothing will happen in the firm & No. & 0 & 0.0 & 100 \\
\hline Total & No. & 82 & 100 & \\
\hline
\end{tabular}

As exhibited in the table 2, the great majority of respondents (75.61 percent) indicated that risk increases due to use of higher debt as compared to other firms in the industry. No response was found with respect to risk decreases. It shows that respondents of the survey have feeing of higher risk employing more debt in capital structure.

In relation to effect on share price, 21.95 percent respondents participating in the survey reported that share price will decrease. It shows that respondents have belief on increase in risk and decrease on share price as a result of using more debt in comparison to similar firms in the industry.

\subsection{Financing preferences and factors governing capital structure decision}

This part of the questionnaire was designed to understand the respondents view on financing preferences for new investment and factors governing the financial leverage decision. In first question respondents were asked to rank the various sources of long-term fund in terms of their importance for financing new profitable investment by assigning 1 for the most important source, 2 for second important and so on and 5 for the least important. Number and percentage of response for each rank together with composite mean has been presented in Table 3.

Table 3: Relative preference of long-term sources of fund for financing new investment

\begin{tabular}{|c|c|c|c|c|c|c|c|c|}
\hline \multirow{2}{*}{$\begin{array}{l}\text { Sources of Long- } \\
\text { term Fund }\end{array}$} & \multicolumn{5}{|c|}{ Rank (1=Most Important; $5=$ Least Important) } & \multirow{2}{*}{ Total } & \multirow{2}{*}{$\begin{array}{l}\text { Composite } \\
\text { Mean }\end{array}$} & \multirow{2}{*}{ Rank } \\
\hline & 1 & 2 & 3 & 4 & 5 & & & \\
\hline Use of Debt & $\begin{array}{c}5 \\
(6.10)\end{array}$ & $\begin{array}{c}65 \\
(79.27)\end{array}$ & $\begin{array}{c}10 \\
(12.20)\end{array}$ & $\begin{array}{c}1 \\
(1.22)\end{array}$ & $\begin{array}{c}1 \\
(1.22)\end{array}$ & $\begin{array}{c}82 \\
(100.0)\end{array}$ & 2.12 & 2 \\
\hline $\begin{array}{l}\text { Issue of } \\
\text { Preferred Stock }\end{array}$ & $\begin{array}{c}0 \\
(0.0)\end{array}$ & $\begin{array}{l}0 \\
(0)\end{array}$ & $\begin{array}{c}57 \\
(69.51)\end{array}$ & $\begin{array}{c}15 \\
(18.29)\end{array}$ & $\begin{array}{c}10 \\
(12.20)\end{array}$ & $\begin{array}{c}82 \\
(100.0)\end{array}$ & 3.43 & 3 \\
\hline Issue of equity & $\begin{array}{c}3 \\
(3.66)\end{array}$ & $\begin{array}{c}5 \\
(6.10)\end{array}$ & $\begin{array}{c}10 \\
(12.20)\end{array}$ & $\begin{array}{c}58 \\
(70.73)\end{array}$ & $\begin{array}{c}6 \\
(7.32)\end{array}$ & $\begin{array}{c}82 \\
(100.0)\end{array}$ & 3.72 & 4 \\
\hline $\begin{array}{l}\text { Use of Retained } \\
\text { earning }\end{array}$ & $\begin{array}{c}72 \\
(87.80)\end{array}$ & $\begin{array}{c}7 \\
(8.54)\end{array}$ & $\begin{array}{c}3 \\
(3.66)\end{array}$ & $\begin{array}{c}0 \\
(0.0)\end{array}$ & $\begin{array}{c}0 \\
(0.0)\end{array}$ & $\begin{array}{c}82 \\
(100.0)\end{array}$ & 1.16 & 1 \\
\hline Others & $\begin{array}{c}2 \\
(2.44)\end{array}$ & $\begin{array}{c}5 \\
(6.09)\end{array}$ & $\begin{array}{c}2 \\
(2.43)\end{array}$ & $\begin{array}{c}8 \\
(9.76)\end{array}$ & $\begin{array}{c}65 \\
(79.26)\end{array}$ & $\begin{array}{c}82 \\
(100.0)\end{array}$ & 4.57 & 5 \\
\hline Total & $\begin{array}{c}82 \\
(100.0)\end{array}$ & $\begin{array}{c}82 \\
(100.0)\end{array}$ & $\begin{array}{c}82 \\
(100.0)\end{array}$ & $\begin{array}{c}82 \\
(100.0)\end{array}$ & $\begin{array}{c}82 \\
(100.0)\end{array}$ & $\begin{array}{c}82 \\
(100.0)\end{array}$ & & \\
\hline
\end{tabular}


As exhibited in Table 3 the great majority of respondents (87.8 percent) ranked use of retained earnings as their first choice. The composite ranking mean of use of retained earnings is the lowest (1.06), and that for others is the highest (4.54). This result implies that use of retained earnings is the first choice and other sources are the last choice in repotting firms.

Issue of preferred has been ranked third by the respondents with the mean rank of 3.44, and external equity has been ranked in next order with the mean rank of 3.85. This pattern of preferences to a greater extent provides an indication towards existence of pecking order financing among the Nepalese non-financial firms.

\subsection{Relative importance of parties influencing on capital structure decision}

Empirical studies based on survey research have made an attempt to examine the influences of various parties associated with firms on setting financial leverage ratio. Among others, one important objective of this study was to understand the respondents view in relation to who exerts major influence on setting target leverage ratio in Nepalese non financial firms.

Table 4: Relative importance of parties influencing on capital structure decision

\begin{tabular}{|c|c|c|c|c|c|c|c|}
\hline \multirow{2}{*}{$\begin{array}{l}\text { Influential parties and their } \\
\text { influence: }\end{array}$} & \multicolumn{7}{|c|}{ Rank (1=Most Important; $5=$ Least Important) } \\
\hline & $\begin{array}{c}\text { Most } \\
\text { important }\end{array}$ & 2 & 3 & 4 & $\begin{array}{c}\text { Least } \\
\text { Important }\end{array}$ & $\begin{array}{c}\text { Composite } \\
\text { Mean }\end{array}$ & Rank \\
\hline Own Management and Staffs & $\begin{array}{c}61 \\
(74.39)\end{array}$ & $\begin{array}{c}17 \\
(20.73)\end{array}$ & $\begin{array}{c}2 \\
(2.44)\end{array}$ & $\begin{array}{c}1 \\
(1.22)\end{array}$ & $\begin{array}{c}1 \\
(1.22)\end{array}$ & 1.34 & 1 \\
\hline Trade Creditors(Suppliers) & $\begin{array}{c}5 \\
(6.10)\end{array}$ & $\begin{array}{c}12 \\
(14.63)\end{array}$ & $\begin{array}{c}58 \\
(70.73)\end{array}$ & $\begin{array}{c}6 \\
(7.32)\end{array}$ & $\begin{array}{c}1 \\
(1.22)\end{array}$ & 2.83 & 3 \\
\hline Outside security Analysts & $\begin{array}{c}0 \\
(0.0)\end{array}$ & $\begin{array}{c}3 \\
(3.66)\end{array}$ & $\begin{array}{c}2 \\
(2.44)\end{array}$ & $\begin{array}{c}44 \\
(53.66)\end{array}$ & $\begin{array}{c}33 \\
(40.24)\end{array}$ & 4.30 & 5 \\
\hline $\begin{array}{l}\text { Comparison with ratio of } \\
\text { Competitors }\end{array}$ & $\begin{array}{c}4 \\
(4.88)\end{array}$ & $\begin{array}{c}7 \\
(8.54)\end{array}$ & $\begin{array}{c}5 \\
(6.10)\end{array}$ & $\begin{array}{c}24 \\
(29.27)\end{array}$ & $\begin{array}{c}42 \\
(51.22)\end{array}$ & 4.13 & 4 \\
\hline Commercial Bankers & $\begin{array}{c}12 \\
(14.63) \\
\end{array}$ & $\begin{array}{c}43 \\
(52.44) \\
\end{array}$ & $\begin{array}{c}15 \\
(18.29)\end{array}$ & $\begin{array}{c}7 \\
(8.53) \\
\end{array}$ & $\begin{array}{c}5 \\
(6.10) \\
\end{array}$ & 2.39 & 2 \\
\hline Total & $\begin{array}{c}82 \\
(100.0)\end{array}$ & $\begin{array}{c}82 \\
(100.0)\end{array}$ & $\begin{array}{c}82 \\
(100.0)\end{array}$ & $\begin{array}{c}82 \\
(100.0)\end{array}$ & $\begin{array}{c}82 \\
(100.0)\end{array}$ & $\begin{array}{c}82 \\
(100.0)\end{array}$ & \\
\hline
\end{tabular}

As presented in Table 4 the most important influencing party on setting target financial leverage is the firm's own management group and staffs (composite mean 1.34) .This item accounted for 74.39 percent of the responses ranked number one. Of the responses ranked number two in importance, commercial bankers dominated the outcomes and accounted for 52.44 percent responses with the composite mean of 2.39. The composite ranking statistics shows that commercial bankers have also major influence on the determination of leverage targets. The survey results show that trade creditors with the composite ranking mean of 2.83 have some impact on the determination of target financial structure choice. The evidence shows that outside security analysts and comparative industry have only a minimal effect on the development of these targets.

\section{Conclusion and discussion}

The study concludes that current state-of-the- art of corporate capital structure in Nepalese non-financial enterprises is characterized by lack of formal policy, use of both income statement and balance sheet based measure of financial leverage, absence of target debt ratio and lack of policy of maintaining spare debt capacity. The financing 
practices are characterized by preference towards internal financing and frequent change in leadership is the most critical challenge for the corporate capital structure decision in Nepalese non-financial enterprises.

\subsection{Discussion}

This study was directed to examine the major firms' specific determinants and current decision of capital structure in Nepalese non-financial firms.

In relation to current decision financial leverage in Nepalese non-financial firms, the survey uncovered that majority of Nepalese lack target debt ratio. In addition, firms have no policy of maintaining spare debt capacity Therefore companies are recommended for setting target debt ratio and policy of maintaining spare debt capacity to take the advantage of tax shield.

As majority respondents have shown their ignorance towards status of financial leverage, Nepalese firms are recommended to publish their status of leverage for the knowledge of concerned stakeholders. Although theories on corporate leverage suggest that often changes in capital structure are made simultaneously with the new investment decision, it has not still got the priority in Nepalese non-financial firms. Therefore, Nepalese non- financial firms are recommended to undertake periodic evaluation of status of their corporate financial leverage.

The survey result shows that preference toward maturity structure of borrowing varied among the Nepalese non-financial firms, and majority of Nepalese firms do not consider interest rate and practice of matching between asset and liabilities structure while they go for borrowing. As proper matching between assets and liabilities structure is required, companies should pay attention towards this aspect.

Regarding the influences of various parties on corporate financial leverage decision, the survey indicated that the most important influencing party on setting target financial leverage is the firm's own management group and staff, followed by commercial bank and trade creditors. Outside security analysts and comparative industry have only a minimal effect on the development of these targets. Therefore, firms are recommended to take consultation with staff, commercial banks and trade creditors while setting their leverage policy.

The survey uncovered that participants are reluctant in deviating from the financing hierarchy and forgotten the growth opportunity. This kind of sentiment of respondents is to be considered by the firms while financing new growth opportunity. Finally, the great majority of respondents have shown their agreement on challenges faced by the firms for corporate financial leverage decision. This evidence shows that there is common consensus among the great majority of participants with regards to the challenges faced by firms to take corporate leverage decision. The survey found that frequent change in leadership has been perceived as the most critical challenge for the corporate financial leverage decision. This aspect is to be duly considered in the process of taking leverage decision in Nepalese non-financial firms.

\section{References}

Ali \& Oztekin (2011). Firm-and country level determinants of corporate leverage: Some new international evidence. Journal of corporate finance, Vol.17(5), pp 1457-1474.

Annuar, M. N., \& Shamsher, M. (1993). Capital Structure. Capital Market Review, 1(2), 171-177. 
Antoniou, A., Guney, Y. \& Paudyal, K. (2001). Determinants of corporate capital structure: Evidence from European countries. Centre for Empirical Research in Finance Department of Economics and Finance, University of Durham, UK

Bancel, F. \& Mitto, U.R. (2004).Cross-country determinants of capital structure choice: A survey of European Firms, Financial Management, (33), 103-132.

Baral K. J. (1996). Capital structure and cost of capital in public sector enterprises in Nepal. Ph. D. Thesis, Faculty of Management. University of Delhi, Delhi.

Bhat, S. (1980). An empirical analysis of the financial structure of small and large Australian manufacturing enterprises. Journal of Small Business Finance,1, 141-154

Bhattarai, Y.R. (2008).Determinants of capital structure: The Nepalese evidence, M.Phil.Thesis, Faculty of Management, Tribhuvan University, Kirtipur.

Chen J.J. (2004). Determinants of Capital Structure of Chinese-listed Companies. Journal of Business Research, 57, pp. 1341-1351

De-Angelo, H \& Masulis, R. W (1980). Optimal capital structures under corporate and personal taxation. The Journal of Financial Economics. 3-29.

Franklin S. \& Muthusamy K. (2010). Leverage, Growth and Profitability as Determinants of Dividend Payout Ratio-Evidence from Indian Paper Industry. Asian Journal of Business Management Studies 1 (1): 26-30,

Gordon, M.J. (1962). The investment, Financing and Valation of Corporation. Homewood III, 1962.

Gupta, M.C. (1969). The Effect of Size, Growth and Industry on the Financial Structure of Manufacturing Companies. Journal of finance, Vol. 24, No, 3.

Gupta, S. L. (1990). Capital structure decision, a comparative study of general engineering and cotton textile Industry. M. Phil. Dissertation: Department of Commerce, Delhi School of Economic, University of Delhi.

Harris, M. \& Raviv, A.(1991). The Theory of Capital Structure. Journal of Finance, Vol.49, pp. 297355.

Jensen, M. \& Meckling, W. (1976). Theory of the firm: managerial behaviour, agency costs and ownership structure. Journal of Financial Economics, 3, 305-360.

Jensen, M.C. (1986). Agency cost of free cash flow, corporate finance and takeovers. American Economic Review, Vol. 76, pp. 323-39.

Jong A., Kabir R., Nguyen T. (2008). Capital Structure around the World: The roles of firm- and country-specific determinants. Journal of Banking \& Finance, Vol. 32.

Jordan, J., Lowe, J. \& Taylor, P. (1998). Strategy and financial policy in UK small firms. Journal of Business Finance and Accounting, 25, 1-27.

Kester, C. W. (1986). Capital and ownership structure: A comparison of United States and Japanese manufacturing corporation. Financial Management, 15(1), 5-16.

Modigliani, F. \& Miller, M. H. (1963). Corporate income taxes and the cost of capital: a correction. American Economic Review, 53(3), 433-43.

Mohanty (2003). A Review of Research on the Practices of Corporate Finance. South Asian Journal of Management; Vol.9; No.4; pp.202-229.

Myers, S. C. \& Majluf. N. S. (1984). Corporate financing and investment decision when firms have information that investors do not have. The Journal of Financial Economics, 13, 187-221,

Myers, S. C. (1984). The capital structure puzzle. Journal of Finance, 34(3), 575-592.

Ozkan A. (2001). Determinants of capital structure and adjustment to long-run target: evidence from UK company panel data. Journal of Business Finance \& Accounting 28, 175-198.

Pandey, I. M. (2001). Capital structure and the firm characteristics: Evidence from the emerging 
market, Indian Institute of Management, Ahmedabad, IIMA working paper No. 2001-2004.

Paudel, R. B. (1994). Industrial finance in Nepal. Ph. D. Thesis, Faculty of Management, Tribhuvan University, Kirtipur.

Qian Y.M., Tian Y., \& Wirjanto T.S. (2007). An Empirical Investigation into the Capital-Structure Determinants of Publicly Listed Companies: A Static Analysis, University of Waterloo

Rajan, R. \& Zingales, L. (1995). What do we know about the capital structure? Some evidence from international data. Journal of Finance, 50: 1421-60.

Ross, S. (1977). The determinants of financial structure: the incentive signaling approach. Bell Journal of Economics, 8, 23- 40.

Sharma, S. K. (1995). Determinants of corporate capital structure: An empirical analysis of selected manufacturing industries in India. Ph. D. Dissertation: University of Delhi.

Sharma, T. \& Preethi, S.K. (2004). Effect on Non-traditional Debt on Financial Risk: Evidence from Indian Manufacturing Firms. Paper Presented at International Conference on Business Finance, 2003.

Shenoy, C. \& Koch, P.D. (1996). The firm's leverage-cash flow relationship. Journal of Empirical Finance, 2, 307-331.

Sherpa, L.G.(2007). Corporate capital structure and its determinants: A case of Nepal, M.Phil. Thesis, Faculty of Management, Tribhuvan University, Kirtipur

Shrestha, M. K. (1985). Analysis of Capital Structure in Selected Public Enterprises. Prashasan: The Nepalese Journal of Public Administration 16: 41-49.

Shrestha, R. D. (1993). Focus on Capital Structure of Selected and Listed Companies. Pravaha Journal of Management 10.

Sinha. S. (1992). Inter industry variation in capital structure in India, Indian Journal of Finance and Research, 2(2), 15- 16.

Stiglitz, J.E. \& A. Weiss( 1981). Credit rationing in markets with imperfect information. American Economic Review, 71, pp. 393-410.

Titman, S. \& Wessel. R. (1988). The determinants of capital structure choice. Journal of Finance, 43(1), 1-19.

Vanyale, N. \& Sharma, A.(2006). Determinants of Capital Structure in Public Enterprises. The ICFAI, Journal of Applied Finance, Vol. 12, No. 7.

Wald, J.K. (1999). How firm characteristics affect capital structure: an international comparison? Journal of Financial Research, 22, 161-87. 